\title{
RANCANG BANGUN APLIKASI AGENDA PELAYANAN KEPENDUDUKAN DAN PENCATATAN SIPIL TERINTEGRASI (STUDI KASUS : UPTD PELAYANAN KEPENDUDUKAN DAN PENCATATAN SIPIL MAJENANG)
}

\author{
Ummu Salamah \\ Fakultas Ilmu komputer, Universitas Amikom Purwokerto \\ email: umuanam@gmail.com
}

\begin{abstract}
Article history Received Sept 16, 2020

Revised Okt 27, 2020

Accepted Nov 8, 2020

Available online Nov 30, 2020

Keywords Application, agenda, population and civil registration, integrated.

UPTD Population and Civil Registration Service Majenang has a service task in the field of population and civil registration. In the field of population serving the printing of KIA, KTP-el and KK. In the field of civil registration, it serves printing birth certificates, death certificates, marriage certificates, divorce certificates, and other civil registration certificates. Each type of service is recorded in a different agenda book. Because it is still manual, data redundancy often occurs, it is less effective in document search and reporting. The research method used is literature study, interview, observation and application development. This application was developed using the waterfall method, web-based, and tested by black box testing. The purpose of this research is to build an integrated population service agenda book application and civil registration so that it can make it easier to record service agendas and present reports more quickly, completely and accurately. The results of the application testing show that the application has run as expected Keywords: Application, agenda, population and civil registration, integrated.
\end{abstract}

\section{Abstrak}

Riwayat Diterima 16 Sept 2020

Revisi 27 Okt, 2020

Disetujui 8 Nov

2020

Terbit 30 Nov

2020

Kata Kunci

Aplikasi, agenda kependudukan dan pencatatan sipil, terintegrasi.
UPTD Pelayanan Kependudukan dan Pencatatan Sipil Majenang mempunyai tugas pelayanan dalam bidang kependudukan dan pencatatan sipil. Dalam bidang kependudukan melayani pencetakan KIA, KTP-el dan KK. Dalam bidang pencatatan sipil melayani pencetakan akta kelahiran, akta kematian, akta perkawinan, akta perceraian, dan akta pencatatan sipil lainnya. Setiap jenis pelayanan dicatat dalam buku agenda yang berbeda. Metode penelitian yang dilakukan adalah studi literatur, wawancara, observasi dan pengembangan aplikasi. Aplikasi ini dikembangkan dengan metode waterfall, berbasis web, dan diuji dengan black box testing. Tujuan dari penelitian ini adalah membangun sebuah aplikasi buku agenda pelayanan kependudukan dan pencatatan sipil yang terintegrasi sehingga dapat mempermudah pencatatan agenda pelayanan dan penyajian laporan yang lebih cepat, lengkap dan akurat. Hasil dari pengujian aplikasi menunjukkan bahwa aplikasi telah berjalan sesuai dengan tujuan yang diharapkan.

Kata Kunci : Aplikasi, agenda, kependudukan dan pencatatan sipil, terintegrasi. 


\section{PENDAHULUAN}

Dinas Kependudukan dan Pencatatan Sipil Kabupaten Cilacap adalah Perangkat pemerintah kabupaten yang bertanggung jawab dan berwenang melaksanakan urusan administrasi kependudukan dan pencatatan sipil berdasarkan asas otonomi daerah dan tugas pembantuan. Dalam melaksanakan sebagian tugas teknis operasional dan/atau teknis penunjang di lingkungan dinas kependudukan dan pencatatan Sipil dapat dibentuk UPTD yang dipimpin oleh kepala UPTD yang berada di bawah dan bertanggungjawab kepada kepala dinas.

UPTD Pelayanan dan Kependudukan Majenang adalah salah satu UPTD Disdukcapil yang memiliki 5 wilayah kerja meliputi Kecamatan Majenang, Kecamatan Karangpucung, Kecamatan Cimanggu, Dayeuhluhur dan Wanareja. UPTD Pelayanan Kependudukan dan pencatatan sipil Majenang mempunyai tugas melaksanakan pelayanan pendaftaran penduduk dan pencatatan sipil meliputi :

1. Penerbitan Kartu Keluarga (KK), Kartu Identitas Anak (KIA), dan Kartu Tanda Penduduk (KTP-el)

2. Penerbitan Akta Pencatatan Sipil ( Akta Kelahiran, kematian, perkawinan, perceraian, pengakuan anak, pengesahan anak dan lain-lain)

3. Penerbitan surat keterangan dan catatan pinggir

4. Legalisasi dokumen kependudukan dan pencatatan sipil

5. Penandatanganan Kartu Keluarga terbitan 5 Kecamatan wilayah kerja

6. Pengajuan request biometrik, konsolidasi manual, dan pengecekan data perekaman KTP-el

Sistem agenda yang berjalan di UPTD Majenang masih manual/non komputerisasi menggunakan buku agenda untuk mencatat agenda pelayanan yang dilaksanakan. Sebagai contoh, pengajuan cetak KTP-el menggunakan buku agenda pencetakan KTP-el yang berisi data KTP-el yang tercetak perhari dengan isian nama, alamat, dan tanda tangan pengambil KTP-el. Untuk pengajuan akta kelahiran dan kematian dicatat dalam buku agenda penerimaan berkas yang mencatat setiap nomer buku register akta kelahiran jenis umum (R), terlambat pendaftaran (TP), terlambat pendaftaran dengan lampiran surat keterangan tidak mampu (TM), dan akta kematian (KM).

Penelitian ini fokus untuk membangun aplikasi buku agenda terintegrasi yang membantu pencatatan pelayanan dan penyajian laporan pada UPTD Pelayanan Kependudukan dan pencatatan sipil Majenang?

Tujuan penelitian ini adalah membangun sebuah aplikasi buku agenda pelayanan kependudukan dan pencatatan sipil pada UPTD Pelayanan Kependudukan dan pencatatan sipil Majenang sehingga dapat mempermudah proses pencatatan agenda pelayanan dan penyajian laporan yang lebih cepat, lengkap dan akurat.

\section{TINJAUAN PUSTAKA}

\section{Sistem Informasi Terintegrasi}

Sistem informasi terintegrasi adalah sistem yang mengolaborasikan dan mengintegrasikan potensi potensi informasi atau data ke dalam suatu wadah berbasis desktop application atau web, di mana fungsinya adalah untuk memudahkan baik itu pengguna internal maupun eksternal organisasi dalam mengelola, menggali, dan menemukan informasi (Perdananugraha, 2010).

\section{Rancang Bangun}

Menurut Jogiyanto (2005), rancang bangun (desain) adalah tahap setelah analisis dari siklus pengembangan sistem yang merupakan pendefinisian dari kebutuhankebutuhan fungsional, serta menggambarkan bagaimana suatu sistem dibentuk yang dapat berupa penggambaran, perencanaan dan pembuatan sketsa atau pengaturan dari beberapa elemen yang terpisah ke dalam satu kesatuan yang utuh dan berfungsi, termasuk menyangkut mengkonfigurasikan komponenkomponen perangkat keras dan perangkat lunak dari suatu sistem.

\section{Use Case}

Use Case merupakan penjelasan singkat fungsi sebuah sistem dari sisi pengguna. Use Case juga menceritakan kumpulan aktivitas yang dilakukan oleh pengguna yang menghasilkan sebuah output dari sistem. Setiap Use Case menggambarkan bagaimana seorang pengguna (user) memicu sebuah kejadian dimana sistem 
harus merespon balik dan memberikan output atas kejadian tersebut (Dennis, Wixom, \& Roth, 2011).

\section{Basis Data}

Basis data atau database merupakan suatu pengorganisasian sekumpulan data yang saling terkait sehingga memudahkan aktivitas untuk memperoleh informasi. Basis data dimaksudkan untuk mengatasi problem pada sistem yang memakai pendekatan berbasis berkas (Kadir, 2003)

\section{Entity Relation Diagram (ERD)}

Entity Relation Diagram (ERD) adalah notasi yang di gunakan untuk melakukan kumenaktivitas pemodelan data. Atribut dari masing-masing objek yang di tulis pada ERD dapat di gambarkan dengan menggunakan deskripsi objek data (Pressman, 2002)

\section{Model Pengembangan Sistem}

Menurut Sasmito (2017), Metode Waterfall merupakan model pengembangan sistem informasi yang sistematik dan sekuensial.

Metode waterfall adalah sebuah metode pembangunan sistem informasi yang memberikan gambaran pendekatan yang sistematis serta berurutan pada pengembangan perangkat lunak, dimulai dengan komunikasi kebutuhan pengguna, tahapan perencanaan, permodelan, konstruksi serta penyerahan sistem ke pengguna yang diakhiri dengan dukungan pada perangkat lunak lengkap yang dihasilkan/after implementation support (Pressman, 2015). Tahapan dalam metode waterfall dapat dilihat pada gambar di bawah ini:

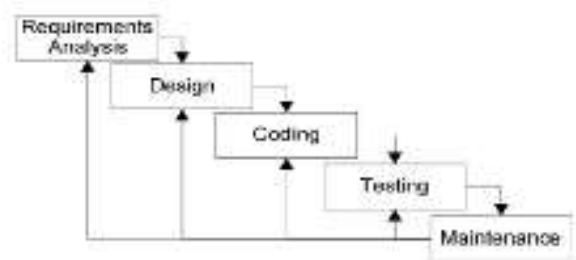

Gambar 1. Tahapan model waterfall

\section{TINJAUAN STUDI}

Beberapa tinjauan studi yang peneliti gunakan dalam penelitian ini antara lain:

- Penelitian yang dilakukan oleh Juniati (2019), yang berjudul "Rancang Bangun Sistem Informasi Administrasi
Kependudukan Berbasis Web di Kantor Kelurahan Bontokamase Kabupaten Bulukumba". Penelitian ini menggunakan metode waterfall dengan bahasa pemrograman $p h p$. Sistem ini bertujuan membangun aplikasi yang bisa meningkatkan kinerja petugas kelurahan dan efisiensi waktu bagi masyarakat mengurus KK/Akta yang terintegrasi dengan email petugas Disdukcapil. Sistem yang terkomputerisasi meminimalisir kesalahan dan memberikan kemudahan dalam pelayanan dan penyajian laporan sebagai dasar pengambilan keputusan.

- Penelitian yang dilakukan oleh Alief alhadi (2019), yang berjudul "Sistem Pelayanan Administrasi Kependudukan terintegrasi di RSUD Arifin Achmad dengan Disdukcapil Kota Pekanbaru dan BPJS Kesehatan anak baru lahir menggunakan REST web service". Penggunaan REST web service mengintegrasikan sistem yang berbeda (BPJS dan Dukcapil) mempermudah RSUD Arifin achmad mengajukan akta kelahiran, akta kematian dan kepersertaan BPJS secara realtime dan efektif. Masyarakat tidak perlu lagi bolak-balik mengurus ke Kantor Disdukcapil dan BPJS Kesehatan.

- Penelitian yang dilakukan oleh Perry Sunandar, Sasongko Pramono Hadi, Wing Wahyu Winarno (2017) yang berjudul "Perancangan Aplikasi Dukcapil Berbasis Android pada Pelayanan Kependudukan dan Catatan Sipil". Metode yang digunakan pada penelitian ini menggunakan Prototype Model yang menghasilkan aplikasi berbasis android untuk pengajuan administrasi kependudukan dengan notifikasi layanan lewat email.

\section{METODE PENELITIAN}

Metode-metode yang digunakan untuk mendapatkan informasi dan data-data yang diperlukan adalah sebagai berikut :

- Wawancara (interview)

Menurut Sutoyo (2012), interview dipandang sebagai teknik pengumpulan data dengan cara tanya jawab lisan yang dilakukan secara sistematis guna mencapai tujuan penelitian. Pada penelitian ini wawancara dilakukan kepada pegawai UPTD Yandukcapil Majenang sebagai pelaksana proses bisnis yang berjalan, 
Kepala UPTD selaku stakeholder penentu kebijakan.

- Pengamatan (Observasi)

Menurut Arifin (2011), observasi adalah suatu proses pengamatan dan pencatatan secara sistematis, logis, objektif dan rasional mengenai berbagai fenomena, baik dalam situasi yang sebenarnya maupun dalam situasi buatan untuk mencapai tujuan tertentu. Pada penelitian ini objek yang diamati adalah proses pencatatan agenda pelayanan kependudukan dan pencatatan sipil pada UPTD Yandukcapil Majenang dan penyajian laporan pelayanan.

\section{- Studi Kepustakaan}

Menurut Sugiyono (2012), Studi kepustakaan merupakan studi yang berkaitan dengan kajian teoritis, literatur ilmiah dan referensi lain yang berkaitan dengan penelitian. Dalam penelitian ini tidak terlepas dari data-data yang terdapat dari jurnal dan literatur yang digunakan dalam perancangan aplikasi agenda pelayanan kependudukan dan pencatatan sipil.

\section{Model Pengembangan Sistem}

Model yang digunakan untuk pembuatan aplikasi agenda berbasis web ini menggunakan framework Laravel. Adapun tahapantahapannya adalah sebagai berikut :

- Analisa Kebutuhan

Peneliti menganalisa sistem agenda yang berjalan di UPTD Yandukcapil Majenang untuk mengidentifikasi dan memahami masalah serta menentukan kebutuhan dan persyaratan fungsional dari sistem yang baru. Dalam hal ini, Peneliti melakukan studi analisa terkait sistem yang ada dan mengusulkan penyelesaian dari masalah yang dihadapi dengan diagram proses bisnis aplikasi.

- Desain

Proses perancangan sistem yang akan diimplementasikan ke dalam program, baik basis data yang dibuat dan design interface yang akan digambarkan oleh ERD dan UML. Dari hasil pengembangan analisis, kemudian membuat sebuah rancangan program (interface) sebagai media pendukung tercapainya rancangan sistem yang baru.

\section{- Code Generation}

Pada tahapan ini hasil dari fase-fase sebelumnya dituangkan kedalam kodekode dengan memasukan hasil desain ke dalam bahasa pemrograman komputer yang telah ditentukan dalam tahap sebelumnya, dalam hal ini penulis menggunakan bahasa pemrograman PHP.

- Testing

Pengujian program dilakukan dengan menggunakan blackbox testing untuk mengetahui kebenaran dari pembuatan program ini secara manual, untuk mendeteksi apakah sudah benar atau belum, sudah sesuai atau belum diuji, sehingga dapat dilakukan perbaikan terlebih dahulu jika menemukan kendala.

- Maintenance (perawatan)

Maintenance (perawatan) adalah pemeliharaan sistem informasi dari segi hardware maupun software. Perawatan sisitem diperlukan agar sistem dapat beroperasi dengan normal untuk mendukung pelaporan pelayanan yang dilakukan.

\section{HASIL DAN PEMBAHASAN Analisa Kebutuhan Software}

Tahap analisis kebutuhan ini dilakukan untuk menganalisa tentang apa saja yang dibutuhkan pengguna. Pengguna dalam aplikasi ini terdiri dari administrator, operator pelayanan dan pimpinan/eksekutif yang masing-masing memiliki hak akses terhadap sistem tersebut.

Kebutuhan masukan atau input yang diperlukan untuk memenuhi kebutuhan dan implementasi sistem antara lain:

1. Data pelayanan umum untuk proses input data pelayanan legalisasi, tanda tangan KK, pembayaran denda keterlambatan Akta pencatatan sipil dan denda perekaman eKTP

2. Data pelayanan kependudukan untuk proses input data pencetakan KIA dan e-KTP

3. Data Pelayanan Pencatatan Sipil untuk proses input data pencetakan akta pencatatan sipil (akta kelahiran, akta kematian, akta perkawinan, akta perceraian, akta perubahan, kutipan kedua dan akta pencatatan sipil lainnya) 
Kebutuhan keluaran yang dihasilkan dari Aplikasi agenda pelayanan kependudukan dan pencatatan sipil ini adalah laporan perolehan denda, pencetakan dokumen kependudukan dan dokumen pencatatan sipil yang dilaksanakan di UPTD Yandukcapil Majenang.

\section{Proses Bisnis Aplikasi}

Pencatatan agenda dilakukan setelah berkas diterima petugas. Pada aplikasi terdapat menu-menu pelayanan yang bisa dipilih untuk mencatat semua jenis pelayanan. Ketika menu dipilih aplikasi menampilkan form isian sesuai pelayanan yang dipilih. Hasil dari isian tersebut ditampilkan dalam bentuk tabel yang mana fungsi edit dan hapus ada di tabel tersebut. Untuk menampilkan laporan user bisa memilih item di menu laporan.

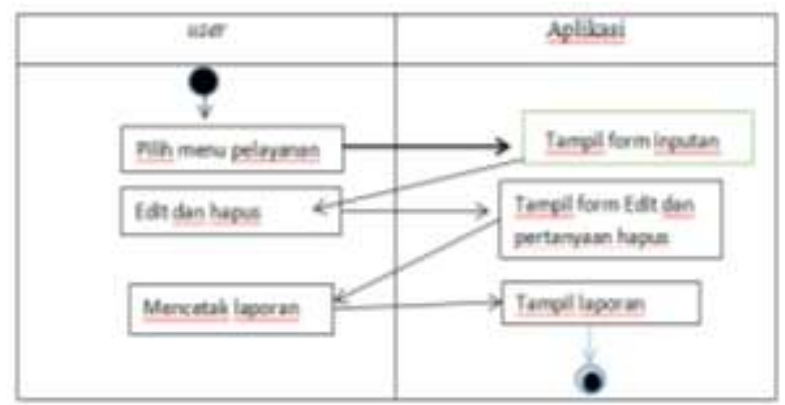

Gambar 2. Activity diagram aplikasi

\section{Use Case Diagram}

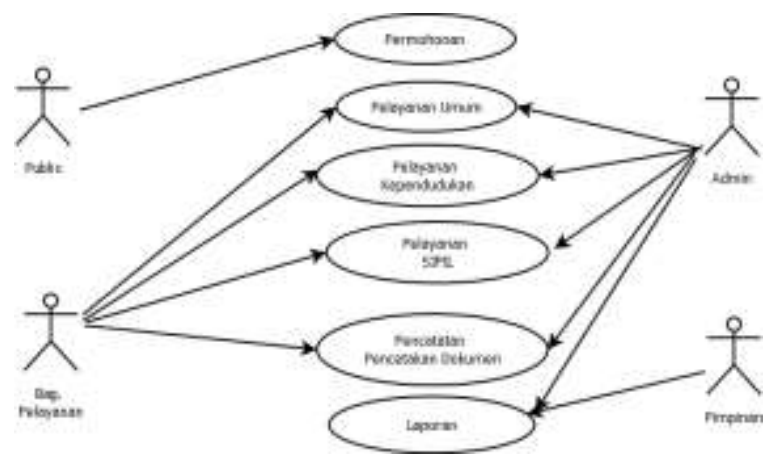

Gambar 3. Use Case Diagram aplikasi

Pada gambar di atas dijelaskan interaksi dari masing-masing user dengan aplikasi. Administrator, operator pelayanan dan pimpinan/eksekutif diharuskan login terlebih dahulu sebelum berinteraksi dengan aplikasi. Administrator memiliki wewenang mengelola data master, data laporan, data inputan semua jenis pelayanan dan setting aplikasi. Operator pelayanan mempunyai wewenang melakukan proses input, hapus, edit data pelayanan dan mencetak laporan. Sedangkan pimpinan bisa mengakses menu laporan sebagai monitoring terhadap pelayanan yang dilaksanakan.

\section{Relasi tabel}

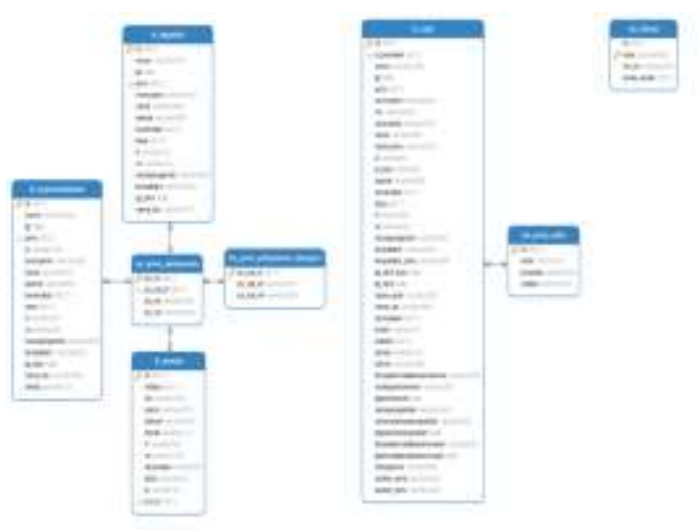

Gambar 4. Relasi antar tabel

\section{Tampilan Login}

Pengguna harus login terlebih dahulu untuk masuk ke dalam sistem seperti pada gambar 5 berikut.

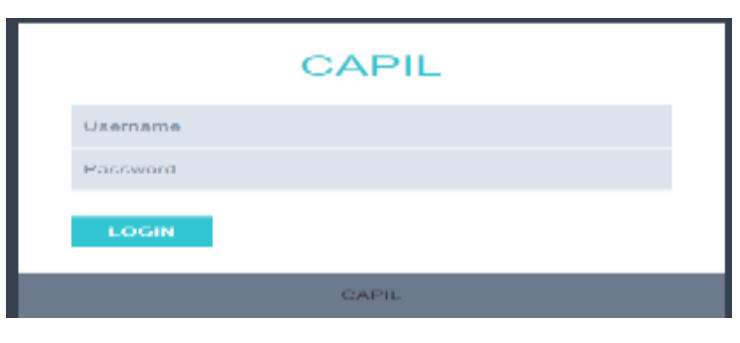

Gambar 5. Tampilan login

\section{Tampilan Menu cetak Kependudukan}

Gambar 6 merupakan menu cetak kependudukan dipilih akan Tampil form untuk input data pencetakan KTP-el dan KIA. Dari inputan tersebut akan ditampilkan hasil inputan dalam bentuk tabel dengan fungsi edit dan hapus. 


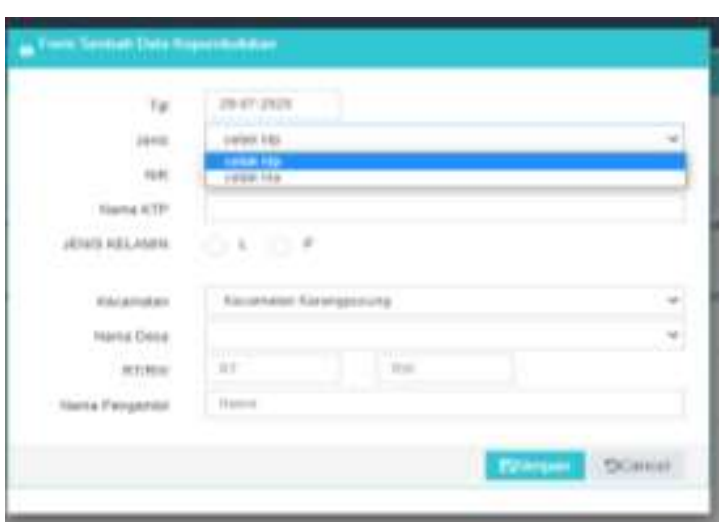

Gambar 6. Tampilan menu cetak kependudukan

\section{Tampilan menu akta kelahiran}

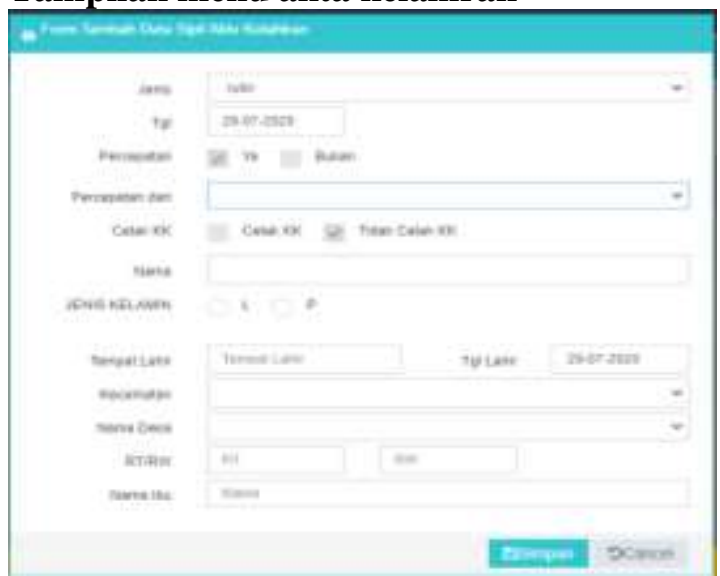

Gambar 7. Tampilan menu akta kelahiran

Berdasarkan gambar 7, pengguna dapat memasukan data akta kelahiran mulai dari jenis akta, program umum/percepatan, cetak KK atau tidak dari berkas akta kelahiran yang diterima, dimana nomer register secara otomatis disetting aplikasi untuk membantu petugas meminimalisir kesalahan nomer register.

\section{Tampilan menu perubahan akta}

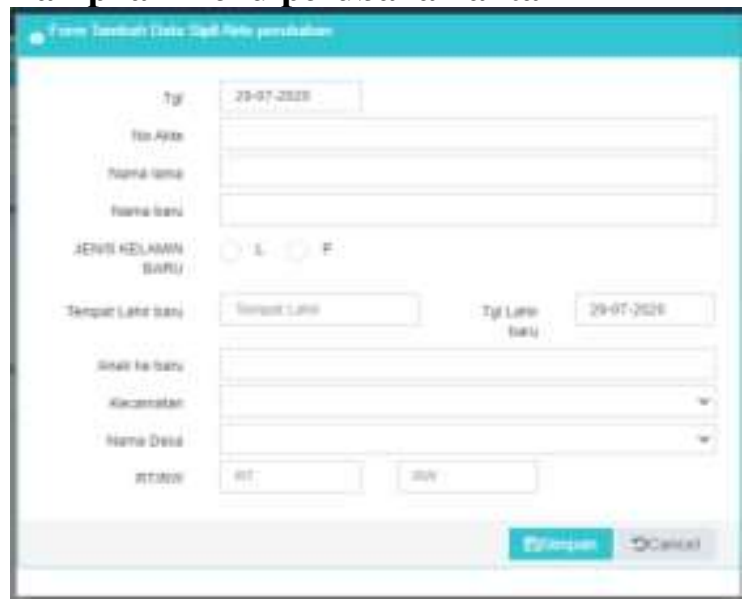

Gambar 8. Tampilan menu perubahan akta

\section{Tampilan menu laporan}

Pada menu laporan, pengguna dapat memilih laporan yang dibutuhkan yaitu laporan harian, laporan percepatan, dan rekap laporan pelayanan seperti pada gambar 9 .

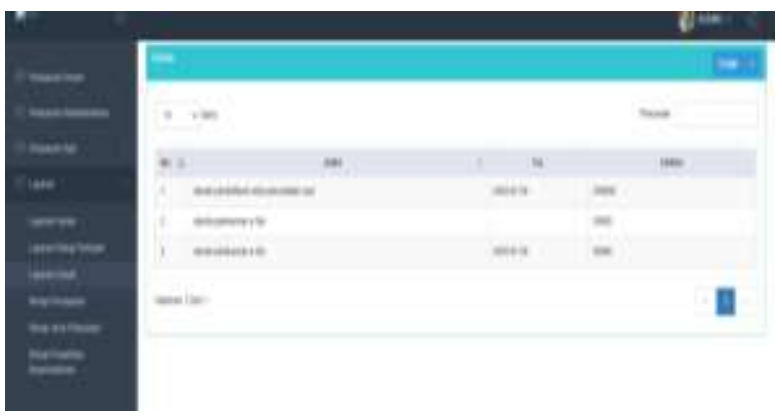

Gambar 9. Tampilan menu laporan

\section{Pengujian Sistem}

Metode yang digunakan dalam proses pengujian aplikasi ini yaitu dengan menggunakan black box testing. Berikut hasil dari pengujian sistem yang dilakukan:

Tabel 1. Hasil Pengujian black box

\begin{tabular}{|l|l|l|}
\hline No & Detail Pengujian & Hasil \\
\hline 1 & Login dan Logout & sesuai \\
\hline 2 & $\begin{array}{l}\text { Input, save dan hapus data } \\
\text { legalisasi dan denda }\end{array}$ & sesuai \\
\hline 3 & $\begin{array}{l}\text { Menampilkan hasil input } \\
\text { data legalisasi dan denda }\end{array}$ & Sesuai \\
\hline 4 & $\begin{array}{l}\text { Input, save dan hapus } \\
\text { cetak kependudukan }\end{array}$ & sesuai \\
\hline 5 & $\begin{array}{l}\text { Menampilkan hasil cetak } \\
\text { kependudukan }\end{array}$ & Sesuai \\
\hline 6 & $\begin{array}{l}\text { Input, save dan hapus akta- } \\
\text { akta pencatatan sipil } \\
\text { kelahiran, kematian, } \\
\text { perkawinan, perceraian, } \\
\text { perubahan dan } \\
\text { hilang/rusak }\end{array}$ & sesuai \\
\hline 7 & $\begin{array}{l}\text { Menampilkan hasil input } \\
\text { akta-akta pencatatan sipil }\end{array}$ & Sesuai \\
\hline 8 & $\begin{array}{l}\text { Mencetak bukti } \\
\text { pembayaran denda }\end{array}$ & sesuai \\
\hline 9 & $\begin{array}{l}\text { Mencetak laporan harian, } \\
\text { laporan percepatan, jenis } \\
\text { pelayanan dan rekap }\end{array}$ & Sesuai \\
\hline
\end{tabular}

\section{KESIMPULAN}

Kesimpulan yang dapat diambil dari hasil penelitian aplikasi agenda pelayanan 
kependudukan dan pencatatan sipil sebagai berikut:

- Penelitian ini telah berhasil membangun aplikasi agenda pelayanan yang dapat diterapkan pada UPTD Pelayanan kependudukan dan pencatatan sipil Majenang.

- Berdasarkan hasil pengujian menggunakan blackbox testing, aplikasi yang dibangun dapat mempermudah pemohon dalam pencatatan agenda pelayanan pada UPTD Yandukcapil Majenang serta dapat menyajikan laporan pelayanan lebih cepat, lengkap dan akurat.

\section{REFERENSI}

A.S. Rosa, \& Shalahuddin, M. 2013. Rekayasa Perangkat Lunak. Informatika. Bandung.

Arief M Rudianto. 2011. Pemrograman Web Dinamis menggunakan PHP dan $M y S Q L . \quad$ CV. ANDI OFFSET. Yogyakarta.

Hardiyansyah. 2011. Kualitas Pelayanan Publik - Konsep, Dimensi, Indikator dan Implementasinya. Gava Media. Yogyakarta.

Madcoms. 2010. Aplikasi Program PHP + MySQL untuk membuat website interaktif. Penerbit Andi. Yogyakarta.

Madcoms. 2016. Pemrograman PHP dan MYSQL untuk Pemula. Penerbit Andi. Yogyakarta.

Nazir, 2012. Metode Penelitian. Ghalia Indonesia. Jakarta.

Pemerintah Kabupaten Cilacap. 2018. Peraturan Bupati Cilacap No. 25 Tahun 2018 tentang pembentukan, kedudukan, susunan organisasi, tugas dan tata kerja unit pelaksana teknis daerah dinas kependudukan dan pencatatan sipil kabupaten Cilacap

Ratminto \& Atik Septi Winarsih. 2013. Manajemen Pelayanan. Pustaka Belajar.Yogyakarta.

Sangadji, 2010. Metodologi Penelitian: Pendekatan Praktis Dalam Penelitian.Penerbit Andi. Yogyakarta

Sugiyono Prof. Dr, 2015. Metodologi Penelitian Kuantitatif Kualitatif dan $R \& D$. Alfabeta. Bandung.

Sujatmiko, Eko. 2012. Kamus Teknologi Informasi dan Komunikasi. Aksarra Sinergi Media. Surakarta.

Sunyoto A, M.Kom, 2007. Ajax Membangun Web Dengan Teknologi Asynchronouse Javascript dan XML. Penerbit Andi. Yogyakarta

Yakub. 2012. Pengantar Sistem Informasi. Graha Ilmu. Yogyakarta.

Zaki. 2012. Aplikasi Database untuk Orang Awam. Maxiom. Palembang. 